\title{
INFLUÊNCIA DAS CONDIÇÕES AMBIENTAIS NA TRANSMISSÃO DA LEPTOSPIROSE ENTRE CRIAÇÕES DE OVINOS E BOVINOS DA REGIÃO DE SOROCABA, SP*
}

\author{
C. Escócio ${ }^{1}$, M.E. Genovez ${ }^{1}$, V. Castro ${ }^{1}$, R.M. Piatti ${ }^{1}$, F.H.L. Gabriel ${ }^{2}$, \\ D.P. Chiebao' ${ }^{2}$, S.S. Azevedo ${ }^{3}$, S.R. Vieira ${ }^{4}$, M. Chiba ${ }^{4}$
}

${ }^{1}$ Instituto Biológico, Centro de Pesquisa e Desenvolvimento de Sanidade Animal, Av. Cons. Rodrigues Alves 1.252, CEP 04014-002, São Paulo, SP; Brasil E-mail: genovez@biologico.sp.gov.br

\section{RESUMO}

Leptospiras excretadas pela urina podem sobreviver por longos períodos em águas de superfície e solos, na dependência do pH e teor de umidade e de matéria orgânica. Investigou-se a influência do meio ambiente na transmissão da leptospirose em dois rebanhos exclusivos de ovinos (A e C) e dois de ovinos consorciados com bovinos (F e H) da região de Sorocaba, SP, no período de dezembro de 2007 a setembro de 2008. Foram examinadas amostras de soro pela reação de soroaglutinação microscópica; de urina, água e solo pelo cultivo para leptospiras e urina de ovinos pela PCR. Condições edafoclimáticas, $\mathrm{pH}$ das águas de superfície e solo, granulometria e permeabilidade do solo foram analisadas. Todos os rebanhos apresentaram pelo menos um animal sororeagente para Leptospira spp. Apenas a PCR de um pool de urina de ovinos $(\mathrm{H})$ foi positiva. Leptospira spp. foi isolada do lago de F. O pH das águas de superfície variou entre 6,0-7,0; e nos solos entre 4,5 e 6,8. Os índices de matéria orgânica em A, C e H variaram de 24 a $35 \mathrm{~g} / \mathrm{dm}^{3}$, e $63 \mathrm{~g} / \mathrm{dm}^{3}$ em F. A composição do solo de A e F mostrou-se franco-argiloarenosa, C argilosa e H franco-siltosa; como texturas mistas são capazes de manter a umidade, principalmente devido a argila. Diante da presença de animais sororeatores e portanto da circulação de Leptospira spp. nos rebanhos, conclui-se que o ciclo de transmissão é dependente da interação sinérgica e antagônica de muitas variáveis; onde o pastejo num habitat com alto teor de umidade parece ser limitante.

PALAVRAS-CHAVE: Leptospirose ovina, ovinos - pastejo bovino em conjunto, condições edafoclimáticas.

\begin{abstract}
THE INFLUENCE OF ENVIRONMENT CONDITIONS ON THE TRANSMISSION OF LEPTOSPIROSIS BETWEEN SHEEP AND CATTLE HERDS OF SOROCABA REGION, SP, BRAZIL. Leptospires excreted by urine are able to survive for long periods in surface water and soil depending on the $\mathrm{pH}$, humidity and organic matter presence. This paper reported the influence of environment conditions on the transmission of leptospirosis in two sheep-only farms (A and C) and two cattle-sheep farms (F and H) from December 2007 to September 2008. Serum samples were examined by microscopic agglutination test; urine, surface water and soil samples were cultured for leptospires, and ovine urine pools were analyzed by PCR. Regional edaphoclimatic conditions, pH of surface water and soil, granulometry and permeability of soil were analyzed. All herds presented at least one reactor to Leptospira spp. Only the PCR of an ovine urine pool of herd $\mathrm{H}$ was positive and Leptospira spp. was isolated from the $\mathrm{F}$ lake. The $\mathrm{pH}$ of water samples ranged from 6.0 to 7.0; while in soil it was around from 4.5 to 6.8. Soil organic matter were 24 to $35 \mathrm{~g} / \mathrm{dm}^{3}$ in $\mathrm{A}, \mathrm{C}$ e H, and $63 \mathrm{~g} / \mathrm{dm} 3$ in F. Soil samples of A and F showed loamy-clay texture; $\mathrm{C}$ had clay soil, and $\mathrm{H}$ loamy-silt soil; as mixed compositions are able to maintain the humidity, mainly where clay is present. As the presence of reactors in all herds indicated the contact with Leptospira spp., it was concluded that the cycle of transmission is dependent on the synergistic and antagonistic interaction of many variables; but the close contact of animals grazing in a high humidity habitat seems to be limiting.
\end{abstract}

KEY WORDS: Ovine leptospirosis, ovine - bovine grazing together, edaphoclimatic conditions.

${ }^{2}$ Polo Apta de Sorocaba, Sorocaba, SP, Brasil

${ }^{3}$ Universidade Federal de Campina Grande, Unidade Acadêmica de Medicina Veterinária, Patos, PB, Brasil.

${ }^{4}$ Instituto Agronômico, Centro de Conservação do Solo, Campinas, SP, Brasil.

*Este trabalho contou com financiamento da FAPESP - Fundação de Amparo à Pesquisa do Estado de São Paulo

Arq. Inst. Biol., São Paulo, v.77, n.3, p.371-379, jul./set., 2010 


\section{INTRODUÇÃO}

Enfermidademundialmente distribuída, a leptospirose é particularmente prevalente nas Américas e considerada endêmica na América Latina eno Caribe, com impacto na economia agropecuária. A ocorrência de leptospirose está estreitamente vinculada aos fatores ambientais, que podem dar lugar a um foco de infecção, cuja amplitude está na dependência de condições favoráveis para manutenção da estirpe de Leptospira spp. (Alvesetal., 1996; GeNOVEZ, etal., 2006).

Teoricamente qualquer sorovar de Leptospira spp. podeinfectar qualquer espécie animal, mas na prática umnúmerolimitado desorovareséendêmicoemuma região ou país em particular. Neste caso, a infecção é determinada pelas espécies animais de contato, pelo(s) sorovar (es) existente (es) naquela propriedade ou região, pelas condições ambientais e climáticas, e ainda depende do manejo e das oportunidades de infecção direta ou indireta (GENOVEZ, et al. 2006). Leptospiras excretadas pela urina ou provenientes de outros materiais clínicos podem sobreviver por longos períodos em solo, na dependência da umidade, $\mathrm{pH}$ e matéria orgânica (FAINE et al., 1999).

A composição granulométrica do solo influi na capacidade de retenção da água e manutenção da umidade necessária a sua sobrevivência e multiplicação. Solos coloidais retêm a umidade e absorvem micro-organismos, presumivelmente permitindo que as leptospiras sobrevivam em condições secas. Águas da chuva e correntezas inundam as rachaduras provocadas pela dessecação, fazendo com que as leptospiras sejam liberadas para o ambiente, atingindo as águas e as camadas superficiais do solo, fechando o ciclo de infecção (SMitH; SelF, 1955; KARASEVA, 1971; EldER et al., 1986). Em solos arenosos (partículas com diâmetro de 0,05 a $2 \mathrm{~mm}$ ), a infiltração da água ocorre mais rapidamente o que facilita a drenagem, resultando em baixa retenção; aqueles com partícula de silte (diâmetro 0,05 a 0,002 $\mathrm{mm}$ ) apresentam permeabilidade menor em relação à areia, porém sua capacidade de retenção é bem maior e solos argilosos (partícula com diâmetro $<0,002 \mathrm{~mm}$ ) possuem maior capacidade de retenção deágua devido à presença de poros muito menores do que nos solos arenosos, portanto, com permeabilidade menor comparada aos solos arenosos e silte.

O solo é o receptáculo final de matéria orgânica composta de resíduos de origem vegetal, animal e dos produtos das transformações que controlam a dinâmica populacional da microbiota ( FAINE et al., 1999; Moreira; SiqueIra, 2002), influenciados pelas condições edafoclimáticas. A presença de matéria orgânica e $\mathrm{pH}$ próximo da neutralidade assumem grande importância na perpetuação de focos de leptospirose numa região (RADOsTiTs et al., 2000).

A presença de matéria orgânica em água e solos contaminados pela urina de animais infectados propicia um importante ambiente para a transmissão deleptospiras, que podem persistir nestas condições por até duas semanas (HenRY et al., 1971). Flutuação na população bacteriana tem sido associada às variações de umidade e teor de matéria orgânica, os quais apresentam importante papel na distribuição de leptospiras. O maior número de isolados de solos ocorre onde há mais de $65 \%$ de umidade, sendo raramente positivos em solos arenoso (TORTEN et al. 1970 apud Henry; JoHNSON, 1978). A matéria orgânica se agrega melhor à argila pela característica da alta retenção de água e pela capacidade de absorver e ceder nutrientes, aumentando as características dinâmicas do solo (LEPSCH, 2002). Solos arenosos são pobres em matéria orgânica por ser rapidamente mineralizada, além da alta permeabilidade e baixa retenção de umidade (OliveIRA, 2005).

Naágua eno solo, leptospiras patogênicas também conseguem sobreviver, dependendo do $\mathrm{pH}$. No solo de plantações de cana-de-açúcar com pH ácido $(6,0)$, leptospiras podem sobreviver por período de até sete semanas, e em solos com poças de água de chuvas, sobrevivem por até três semanas (LEVETT, 2001).

A ocorrência e a transmissão da leptospirose são influenciadas pelas características do agente infeccioso, à suscetibilidade de hospedeiros, concentração demográfica, movimentação, interação entreespécies e populações, finalidade de uso dos animais e, sobretudo, pelas condições ambientais que permitem sua manutenção e multiplicação (HerHolz et al., 2006).

O objetivo deste trabalho foi investigar a influência das condições ambientais e edafoclimáticas regionais como predisponentes à infecção por Leptospira spp. e sua transmissão entre ovinos e bovinos.

\section{MATERIAL E MÉTODOS}

Foram estudados quatro rebanhos da região de Sorocaba, SP, sendo dois de criação exclusiva de ovinos (A e C ) mestiços das raças Suffolk, Dorper e Santa Inês, de várias idades, predominantemente fêmeas, criados em regime semi-intensivo e dois de ovinos mestiços das raças Suffolk, Poll Dorset, Santa Inês e Paraíso, de várias idades, predominantemente fêmeas, consorciados com bovinos sem raça definida (HeF), criados em regime extensivo, que não haviam recebido vacinação contra leptospirose. Orebanho A, embora em pastejo, tinha acesso restrito as águas de superfície, contando com um bebedouro. Os rebanhos $\mathrm{C}, \mathrm{He} \mathrm{F}$ tinham acesso a rios, lagos e mananciais para água de bebida, assim como pastejo em várzeas.

Na estação das chuvas foram colhidas amostras sorológicas de $100 \%$ dos animais adultos e analisadas pela Soroaglutinação Microscópica - SAM, frente a 26 sorovares segundo ElLIS (1994). Para o cálculo da soroprevalência da leptospirose foram 
colhidas amostras de soro de $100 \%$ dos animais nos quatro rebanhos, e considerado o número de reações positivas sobre o total de animais (por espécie) da propriedade, definindo-se como o provável sorovar infectante o mais frequente e que apresentou maior título na SAM. Também durante a estação das chuvas, amostras de urina de $10 \%$ destes animais foram cultivadas para leptospiras empregando-se meios EMJH (Difco) e Fletcher (Difco) adicionados de mistura antibiótica 5-fluoracil 1\% e ácido nalidíxico 4\% (Alves et al., 1996) e mantidos a $30^{\circ} \mathrm{C}$ por 24 horas. Um $\mathrm{mL}$ de cada amostra foi transferido para EMJH e Fletcher livres de antibióticos. Uma alíquota das amostras de urina foi filtrada em pré-filtro $0,45 \mu \mathrm{e}$ filtro Millipore $0,65 \mu$ e três a quatro gotas do filtrado foram semeadas em tubos com EMJH, sem solução antibiótica. Outra alíquota foi submetida à diluição seriada $\left(10^{-1}\right.$ a $\left.10^{-4}\right)$ e semeada em meio EMJHeFletcher sem antibióticos (GALton et al., 1962). Todos os tubos foram incubados em condições aeróbicas a $30^{\circ} \mathrm{C}$ por 60 dias, com leituras semanais, em microscópio Jena Zeiss com condensador de campo escuro seco, com lente objetiva Epiplan 20x/0,20 e de ocular 10 (100X).

Oito pools de amostras de urina de dois ou três ovinos, quatro provenientes dos rebanhos exclusivos deovinos equatro dos consorciados, eainda dois pools de dois bovinos das criações consorciadas foram submetidas à técnica da Reação em Cadeia pela Polimerase (PCR) para detecção do DNA gênero-especifico de Leptospira spp. A extração do DNA foi realizada por fervura-fenol (RichtZENHAIN et al., 2002) eempregados os primers gênero específicos Lep1 e Lep2, Leptospira spp. - fragmento de 331 pb: Lep 1: 5' GGC GGC GCG TCT TAA ACA TG 3' e Lep 2: 3' TTC CCC CCA TTG AGCAAG ATT5'(MérIENetal., 1992). Ogel foi corado com brometo de etídeo $0,5 \mu \mathrm{g} / \mathrm{mL}$ e posteriormente fotografado sob luz ultravioleta $(300-320 \mathrm{~nm})$ pelo sistema defoto-documentação(Câmera Kodak Digital DC/120 Zoom) e analisado com o software 1D Image Analysis (Kodak Digital Science).

Foi realizado o cultivo microbiológico de oito amostras de aproximadamente 100 gramas de solo, duas ou três por propriedade foram colhidas pela manhã, em inicio do mês de abril de 2008, às margens de regiões de pastejo próximas a alagados, lagos, rios e mananciais e ainda da pastagem central, e nove amostras de $20 \mathrm{~mL}$ da água de superfície que serviam de bebida e do bebedouro. As amostras de águas foram centrifugadas a $5.000 \mathrm{Xg}$ por 15 minutos e uma alíquota dos sobrenadantes foi observada em microscopia de campo escuro. Um $\mathrm{mL}$ do restante foi cultivado como descrito para urina. Um grama da amostra de solo foi suspensa em $5 \mathrm{~mL}$ de água destilada estéril e alíquotas da suspensão foram cultivadas conforme protocolo para urina. Devido a extensão da propriedade $C$ foram escolhidos dois locais para a colheita das amostras de solo.
Após a colheita, foi medido o $\mathrm{pH}$ das amostras de águas e das suspensões de solo.

A permeabilidade do solo (infiltrações) foi medida em abril/2008, época chuvosa, e em setembro/2008, estiagem, e realizada por meio do permeâmetro de campo de carga constante modelo IAC - Instituto Agronômico (VIEIRA, 1995/1998).

A análise granulométrica foi realizada segundo CAMARGo et al. (1986) e VAN RAIJ et al. (1987).

A determinação de matéria orgânica e do teor de micronutrientes foi realizada pelo método WalkleyBlack ( CAMARGO et al., 1986; VAN RAIJ et al., 1987).

Os dados pluviométricos e as variações térmicas da região de Sorocaba, SP, constantes na Tabela 2, foram obtidos no Centro Integrado de Informações Agrometeorológicas - CIIAGRO.

\section{RESULTADOS}

Nas propriedades de criação exclusivas de ovinos; o rebanho A apresentou apenas um animal sororeagente para o sorovar Pyrogenes (1/91) correspondendo a $1,1 \%$ do total de ovinos e no rebanho C, 6/37 (16,2\%) sororeagentes para o sorovar Autumnalis (Tabela 1).

Nos rebanhos consorciados (Tabela 1), F apresentou $9 / 44(20,45 \%)$ animais reagentes para Leptospira spp., com prevalência do sorogrupo Sejroe; sorovares Hardjo ou com ocorrência de reações cruzadas de mesma magnitude entre os sorovares Hardjo e Wolffi (6/9); e H apresentou 21/83 (25,3\%) animais reagentes para Leptospira spp., sendo prevalentes os sorovares Icterohaemorrhagiae 8/21 (38,1\%), Hardjo e /ou Wolffi 4/21 (19\%).

Os títulos sorológicos em ambas as condições criatórias variaram entre 50 a 3.200 , sendo 1.600 para o sorovar Icterohaemorrhagiae e 3.200 para o sorovar Brastilava.

As amostras de urina não apresentaram crescimento de Leptospira spp. nas leituras semanais realizadas durante 60 dias. Apenas um dos pools de amostras de urinas dos ovinos do rebanho $\mathrm{H}$ foi positivo na PCR correspondendo ao DNA de Leptospira spp. (331 pb), frente ao primer gênero especifico Lep 1 e Lep 2 (MérIEN et al., 1992).

Apenas de uma amostra de água de superfície da margem do lago utilizado como água de bebida para os ovinos e bovinos da propriedade F foi isolada Leptospira spp., com crescimento em EMJH e em meio de Fletcher; tendo sido também confirmada na PCR.

Os índices pluviométricos mensais e as variações de temperatura estão apresentados na Tabela 2.

As análises de permeabilidade, granulometria, índice de matéria orgânica teor de micronutrientes, pH estão apresentadas na Tabela 3. 
Tabela 1 - Soroprevalência para leptospirose nos rebanhos de criação exclusiva de ovinos e consorciada com bovinos da região de Sorocaba, SP, 2008.

\begin{tabular}{|c|c|c|c|c|c|}
\hline $\begin{array}{c}\text { Identificação da } \\
\text { propriedade }\end{array}$ & $\begin{array}{l}\text { Condição do } \\
\text { rebanho }\end{array}$ & $\begin{array}{c}\text { Total de animais } \\
\text { por espécie }\end{array}$ & $\begin{array}{c}\text { Soro prevalência } \\
(\%)\end{array}$ & $\begin{array}{c}\text { Sorovares prevalen- } \\
\text { tes }(\%)\end{array}$ & Outros sorovares \\
\hline $\begin{array}{l}\mathrm{A} \\
\mathrm{C}\end{array}$ & $\begin{array}{l}\mathrm{O} \\
\mathrm{O}\end{array}$ & $\begin{array}{l}\text { Ovinos } 91 \\
\text { Ovinos } 37\end{array}$ & $\begin{array}{c}1 / 91(1,1 \%) \\
6 / 37(16,2 \%)\end{array}$ & $\begin{array}{l}\text { Pyrogenes (1/1) } \\
\text { Autumnalis (5/6) }\end{array}$ & $\begin{array}{c}- \\
\text { 1/6 Icterohaemorrhagiae+ } \\
\text { Pyrogenes+ Autumnalis }\end{array}$ \\
\hline $\mathrm{F}$ & C & $\begin{array}{c}\text { Bovinos } 14 \text { Ovinos } \\
30\end{array}$ & $\begin{array}{c}\text { 9/44 }(20,45 \%) \\
3 / 14 \text { bovinos e } \\
\text { 6/30 ovinos }\end{array}$ & $\begin{array}{c}\text { Hardjo ou Hardjo e } \\
\text { Wolffi }(6 / 9)\end{array}$ & $\begin{array}{l}\text { Ovinos: } 1 / 6 \text { Pomona Bo- } \\
\text { vinos: } 1 / 3 \text { Hebdomadis, } \\
\text { 1/3 Bratislava+Shermani }\end{array}$ \\
\hline $\mathrm{H}$ & C & $\begin{array}{c}\text { Bovinos } 03 \text { Ovinos } \\
80\end{array}$ & $\begin{array}{c}21 / 83 \\
(25,3 \%): 1 / 3 \\
\text { bovinos e } 20 / 80 \\
\text { ovinos }\end{array}$ & $\begin{array}{l}\text { Icterohaemorrha- } \\
\text { giae }(8 / 21)\end{array}$ & $\begin{array}{c}\text { Ovinos: } 2 / 20 \\
\text { Grippotyphosa; } 1 / 20 \\
\text { Pyrogenes; } 3 / 20 \text { Hardjo; } \\
\text { 4/20Autumnalis; } \\
\text { 2/20Bratislava Bovinos: } \\
\text { 1/1 Shermani }\end{array}$ \\
\hline
\end{tabular}

O-Rebanho exclusivo de ovinos.

C-Rebanho consorciado de ovinos e bovinos.

Tabela 2 - Observações termo-pluviométricas no período de dezembro de 2007 a setembro de 2008 da região de Sorocaba, SP, 2008.

\begin{tabular}{lccc}
\hline Mês/ano & Pluviometria/chuva (mm) & \multicolumn{2}{c}{ Temperatura } \\
& & Média/máxima & Média/mínima \\
\hline dezembro/07 & 245,1 & 27,3 & 16,5 \\
janeiro/08 & 190 & 25,11 & 17,06 \\
fevereiro* & 50,4 & 26,9 & 16,8 \\
março/08* & 156,4 & 26,8 & 16,8 \\
abril/08** & 85,5 & 23,4 & 15,3 \\
maio/08 & 93,0 & 21,3 & 11,2 \\
junho/o8 & 60,0 & 21,7 & 11,5 \\
julho/08 & 0,0 & 24,3 & 9,1 \\
agosto/08 & 66,0 & 23,3 & 12,4 \\
setembro/08 ** & 64,0 & 22,3 & 12,3 \\
\hline
\end{tabular}

Fonte: www.ciiagro.sp.gov.br, vários acessos 2008.

* colheitas sorológicas do total de animais adultos para estudo de prevalência e amostras de urina para cultivo.

** colheita de amostras de solo das pastagens e águas para cultivo e para análise da permeabilidade e granulometria.

\section{DISCUSSÃO}

A infecção e transmissão de leptospiras estão relacionadas às exposições aos fatores de risco ambientais, incluindo o contato com animais silvestres ou domésticos. Nos rebanhos exclusivos de ovinos alguns sorovares foram identificados pela SAM, com empate em frequência e magnitude de título, principalmente entre aqueles do sorogrupo Sejroe, Hardjo e Wolffi. No rebanho A, por se tratar de criação semiextensiva em relevo bastante irregular havia certa limitação ao acesso às águas de superfície, um único animal foi sororeagente para sorovar Pyrogenes; entretanto, nos demais rebanhos de criação extensiva e com amplo acesso às águas de superfície, observou-se maior número de animais sororeagentes a vários sorovares, discriminados na Tabela 1.

O sorovar Pyrogenes tem sido relatado em inquéritos sorológicos nas espécies bovina, ovina e suína deforma esporádica, podendo ser caracterizada infecção acidental (FAVERO et al., 2002; HERMANN et al., 2004; GrEgory et al., 2007; CASTRO et al., 2008).

O sorovar Autumnalis, detectado apenas nos ovinos das criações $\mathrm{C}$ e $\mathrm{H}$, parece relacionado a uma 
fonte deinfecçãocomuma esta espécie, supostamente relativa ao manejo desses animais. Nos inquéritos sorológicos para leptospirose realizados na Bahia, por VIEGAs et al. (1980) no Rio Grande do Norte por AzEvedo et al. (2004) e no Rio Grande do Sul por SILva et al. (2007) foi verificada a prevalência deste sorovar nesta espécie animal.

O sorovar Icterohaemorrhagiae ocorreu na propriedade $\mathrm{H}$, em 8/21 (3,6\%) animais reatores, ovinos e bovinos. Este sorovar geralmente está relacionado à presença de roedores, bastante frequentes nas criações animais, caracterizando infecção acidental aos demais hospedeiros. FAVEro et al. (2002), no Estado de São Paulo, identificaram o sorovar Icterohaemorrhagiae em 0,70\% (2/284) ovinos positivos e discutem o envolvimento de roedores sinantrópicos nas criações de ovinos.

O sorovar Hardjo foi detectado apenas nos animais dos rebanhos consorciados, nos quais ovinos são criados de forma extensiva em pastejo com bovinos. Genovez et al. (2006), num estudo com oito rebanhos consorciados e exclusivos de ovinos, verificaram reatividade ao sorovar Hardjo apenas nos consorciados, concluíndo que o bovino se comporta como reservatório deste sorovar e, portanto, transmissor para outras espécies, inclusive ovinos. Discordantes, portanto, de CoUSINS; ROBERTSON (1986) apud CoUSINS et al. (1989) e de GERRITSEN et al. (1994) que apontaram os ovinos como mantenedores do sorovar Hardjo.

Em um rebanho, respostas a múltiplos sorovares naSAM indicam exposições de várias origens, inclusive animais silvestres, mas não descartam a possibilidade de contágio devido à introdução de animais infectados e excretores renais como transmissores e contaminadores do meio ambiente de pastejo e de águas de bebida. Uma vez que os rebanhos nãoforam monitorados sorologicamente, não se pode excluir futura alteração do perfil sorológico no qual prevalecerá um sorovar infectante ou então a ocorrência de surto de leptospirose com perdas reprodutivas.

Visando avaliar a ocorrência de excreção urinária como fonte de infecção entre os animais que compartilhavam o mesmo habitat, foi aplicada a PCR em pools de urina. Apenas um pool de urina de ovinos da propriedade $\mathrm{H}$ confirmou que leptospiras estavam sendo excretadas para o meio ambiente. Analisando-se os resultados sorológicos dos animais que compuseram o pool positivo do rebanho $\mathrm{H}$ e os demais pools, foi verificado que era composto de urina de ovinos sorologicamente negativos no momento da colheita. Esta observação remete a duas hipóteses: os ovinos poderiam estar no início da infecção e, portanto, os níveis de anticorpos estariam abaixo do limiar de detecção da SAM ou, então, tratava-se de portadores renais, assintomáticos e não reagentes. De qualquer maneira, 20/80 (25\%) ovinos haviam sido infecta- dos com Leptospira spp., com prevalência para Icterohaemorragiae; portanto havia circulação e disseminação de leptospiras neste rebanho. Em suma, a excreção de leptospiras estava presente e, portanto, seria possível o isolamento não somente da urina como também das amostras de águas e solo dos locais de maior concentração de animais no pastejo.

Denota-se que a região de Sorocaba (Tabela 2) se caracteriza como clima subtropical (http:// pt.wikipedia.org/wiki/Sorocaba\#Clima), constantemente quente e úmido, com temperaturas amenas na maior parte do ano, não se verificando níveis extremos de frio ou calor. O índice pluviométrico regional foi analisado em relação às datas das co-lheitas sorológicas, ou seja, em 28 de fevereiro; 6, 10 e 18 de março/ 2008 resultando no acumulado de $206,8 \mathrm{~mm}$.

A permeabilidade do solo às águas das chuvas depende diretamente da sua granulometria, textura e a composição, as quais determinam sua capacidade de manutenção do teor de umidade. O fluxo de água (permeabilidade) das pastagens das propriedades foi medido em duas épocas (Tabela 3), chuvosa e estiagem, respectivamente nos meses de abril e setembro de 2008. Solos com orifícios menores, como os solos argilosos, possuem menor permeabilidade, porém apresentam maior retenção de água; solos com orifícios maiores, como os solos formados por areia, possuem maior permeabilidade, mas não permitem maior retenção de água (VIEIRA; CHIBA, informação pessoal). Com exceção do solo da propriedade $C$, cuja permeabilidade foi maior que as demais no período de estiagem, as outras propriedades apresentaram pouca variação, sendo considerados solos de composição mista do tipo argilossolo, o qual contém uma camada superficial de argila iluvial com grande capacidade de manutenção de elevado teor de umidade.

Uma vez que a temperatura e a umidade regional, devido ao índice de precipitação, quando analisadas juntamente com a permeabilidade do solo, mostraram-se propícias à manutenção de focos de leptospiras, o pH e os índices de matéria orgânica poderiam ser limitante na sobrevivência e na multiplicação da bactéria.

Diferentemente das demais propriedades que apresentavam $\mathrm{pH}$ das águas de superfície e de solo próximos a neutralidade, o $\mathrm{pH}$ na propriedade $\mathrm{C}$ mostrou-se ácido (média 4,0) e limitante à sobrevivência de leptospiras (Tabela 3). Gordon SMITH; TURNER (1961) analisaram o tempo e a sobrevivência de leptospiras em diferentes condições de $\mathrm{pH}$ (5,3 a $8,0)$. Estes micro-organismos sobreviveram de 10 a 117 dias em pH abaixo de 7,0 e de 21 a 152 dias em pH acima de 7,0; mesmo em pH 5,3, foram capazes de sobreviver por pelo menos dez dias. 


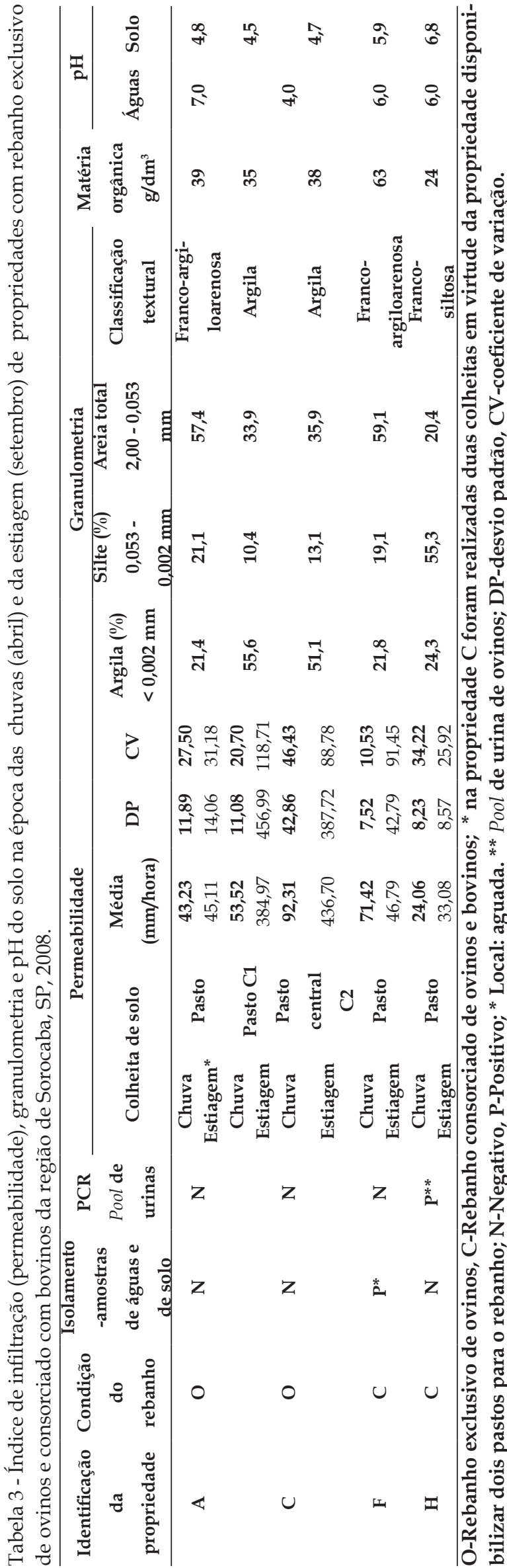

A composição da matéria orgânica aparentemente não diferia nos diversos locais de pastejo onde as amostras de solo e águas haviam sido colhidas. A quantidade de matéria orgânica em $\mathrm{F}$ foi superior às demais propriedades $\left(63 \mathrm{~g} / \mathrm{dm}^{3}\right)$, entretanto, não houve significância estatística em relação aos níveis de matéria orgânica das demais propriedades.

A região de Sorocaba, no Estado de São Paulo possui grandes reservas minerais de rochas calcárias, areia, argila e granito (SÃo PAULO, 2003). Ferro, manganês e zinco são menos disponíveis em valores de $\mathrm{pH}$ acima de 7,0. Ferro, alumínio e manganês atingem níveis tóxicos em valores de $\mathrm{pH}$ menores que 5,0. Fósforo é menos disponível em valores altos ou baixos de $\mathrm{pH}$ (MOREIRA; SiqueIRA, 2002). Sendo o ferro um micronutriente importante para os organismos, a presença ou ausência deste nutriente para leptospiras pode determinar a sua sobrevivência no meio. Comparando-se os índices de micronutrientes disponíveis nos solos, pode-se observar que há disposição de ferro nos solos das propriedades A, C e F, favorecendo a permanência de leptospiras, porém inferior à $\mathrm{H}$. VIEIRA, 1975; BRADYUma vez que todos os rebanhos estavam expostos a fatores de risco para infecção por leptospiras, pois pelo menos um animal apresentava-se sororeator na SAM (Tabela 1), e que as condições edafoclimáticas sustentavam a manutenção deste agente em solo e águas de superfície, restava compreender o sucesso do isolamento de Leptospira spp. da amostra de água colhida às margens da lagoa da propriedade $\mathrm{F}$ em detrimento das amostras semelhantes das demais propriedades. Embora os procedimentos decultivo para isolamento de leptospiras te-nham sido realizados de maneira a contemplar o menor número de limitações à sobrevivência e multiplicação do micro-organismo nas amostras de materiais clínicos ou ambientais, o número de isolados foi limitado. Critérios e cuidados especiais com assepsia na colheita dos materiais clínicos e também ambientais foram tomados, sendo pouco provável que tenha ocorrido contaminação com microorganismos de microbiota animal ou ambiental. A inconsistência do isolamento indica maior complexidade da sobrevivência de leptospiras, talvez com elevada dependência da concentração da bactéria lançada ao meio ambiente e, desta forma, pequenas variações na composição ou quantidade de matéria orgânica ou $\mathrm{pH}$ sejam impedientes, o que explicaria o sucesso em $\mathrm{F}$.

A presença de nutrientes, teor de umidade e $\mathrm{pH}$ próximo a neutralidade, essenciais para a manutenção de focos deleptospiras num ambiente, não foram determinantes para o sucesso na frequência de isolados. 
Tabela 4 - Índice de matéria orgânica e de micronutrientes nas amostras de solo de propriedades com rebanho exclusivo de ovinos e consorciado com bovinos da região de Sorocaba, SP, 2008.

\begin{tabular}{|c|c|c|c|c|c|c|c|}
\hline \multicolumn{3}{|c|}{ Determinações } & \multicolumn{5}{|c|}{ Amostras de solo } \\
\hline Sigla & Descrição & Unidade & $\mathrm{A}$ & $\mathrm{C} 1$ & C2 & $\mathrm{F}$ & $\mathrm{H}$ \\
\hline M.O. & Matéria orgânica & $\mathrm{g} / \mathrm{dm}^{3}$ & 39 & 35 & 38 & 63 & 24 \\
\hline $\mathrm{V}$ & Saturação de bases & $\%$ & 62 & 38 & 49 & 90 & 96 \\
\hline $\mathrm{P}$ & Fósforo resina & $\mathrm{mg} / \mathrm{dm}^{3}$ & 14 & 5 & 7 & 691 & 9 \\
\hline K & Potássio & $\mathrm{mmol}_{\mathrm{c}} / \mathrm{dm}^{3}$ & 3,1 & 2,0 & 3,7 & 5,9 & 2,3 \\
\hline $\mathrm{Ca}$ & Cálcio & $\mathrm{mmol}_{\mathrm{c}} / \mathrm{dm}^{3}$ & 47 & 21 & 39 & 144 & 152 \\
\hline $\mathrm{Mg}$ & Magnésio & $\mathrm{mmol}_{\mathrm{c}} / \mathrm{dm}^{3}$ & 7 & 6 & 12 & 27 & 86 \\
\hline $\mathrm{Na}$ & Sódio & $\mathrm{mmol}_{\mathrm{c}} / \mathrm{dm}^{3}$ & - & - & - & - & - \\
\hline $\mathrm{Al}$ & Alumínio & $\mathrm{mmol}_{\mathrm{c}} / \mathrm{dm}^{3}$ & - & - & - & - & - \\
\hline $\mathrm{H}+\mathrm{Al}$ & Ac. potencial & $\mathrm{mmol}_{\mathrm{c}} / \mathrm{dm}^{3}$ & 34 & 47 & 47 & 20 & 10 \\
\hline S.B. & Soma bases & $\mathrm{mmol}_{\mathrm{c}} / \mathrm{dm}^{3}$ & 57,1 & 29,0 & 45,7 & 176,9 & 250,3 \\
\hline СТС & Capacidade de troca vatiônica & $\mathrm{mmol}_{\mathrm{c}} / \mathrm{dm}^{3}$ & 91,4 & 76,0 & 92,7 & 197,1 & 260,0 \\
\hline S & Enxofre & $\mathrm{mg} / \mathrm{dm}^{3}$ & - & - & - & - & - \\
\hline B & Boro & $\mathrm{mg} / \mathrm{dm}^{3}$ & 0,20 & 0,22 & 0,25 & 0,45 & 0,07 \\
\hline $\mathrm{Cu}$ & Cobre & $\mathrm{mg} / \mathrm{dm}^{3}$ & 0,7 & 1,1 & 1,2 & 8,4 & 2,0 \\
\hline $\mathrm{Fe}$ & Ferro & $\mathrm{mg} / \mathrm{dm}^{3}$ & 82 & 85 & 109 & 79 & 16 \\
\hline Mn & Manganês & $\mathrm{mg} / \mathrm{dm}^{3}$ & 13,4 & 4,6 & 3,4 & 30,7 & 28,7 \\
\hline $\mathrm{Zn}$ & Zinco & $\mathrm{mg} / \mathrm{dm}^{3}$ & 2,3 & 0,6 & 1,0 & 17,0 & 0,6 \\
\hline
\end{tabular}

${ }^{*}$ Na propriedade $C$ foram realizadas duas colheitas em virtude da propriedade disponibilizar dois pastos para o rebanho. - : não detectado

Desta forma, conclui-se que a sobrevivência e multiplicação de leptospiras num habitat e sua virulência estariam condicionadas à resultante dos efeitos sinérgicos e antagônicos de inúmeras variáveis. Entretanto, o contato estreito proporcionado pelo aglomerado de animais excretores em pastejo num habitat com elevada retenção de água parece ser limitante para o ciclo de transmissão interespécie ou intraespécie.

\section{REFERÊNCIAS}

ALVES, C.J.; VASCONCELLOS, S.A.; CAMARGO, C.R.A.; MORAIS, Z.M. Influência dos fatores ambientais sobre a proporção de caprinos soro-reatores para a leptospirose em cinco centros de criação do Estado da Paraíba, Brasil. Arquivos do Instituto Biológico, São Paulo, v.63, n.2, p.11-8, 1996.

AZEVEDO, S.S.; ALVES, C.J.; ANDRADE, J.S.L.; BATISTA, C.S.A.; CLMENTINO, I.J.; SANTOS, F.A. Ocorrência de aglutininas anti-Leptospira em ovinos do estado do Rio Grande do Norte, Brasil. Revista Brasileira de Ciência Veterinária, v.11, n.3, p.167-170, 2004.

CAMARGO, O.A.; MONIZ, A.C.; JORGE, J.A.; VALADARES, J.M.A.S. Métodos de análise química, mineralógica e física de solos do Instituto Agronômico de Campinas. Boletim Técnico do Instituto Agronômico, v.106, p.55-60, 1986.
CASTRO, V.; AZEVEDO, S.S.; GOTTI, T.B.; BATISTA, C.S.A.; GENTILI, J.; MORAES, Z.M.; SOUZA, G.O.; VASCONCELLOS, S.A.; GENOVEZ, M.E. Soroprevalência da leptospirose em fêmeas bovinas em idade reprodutiva no Estado de São Paulo, Brasil Arquivos do Instituto Biológico, São Paulo, v.75, n.1, p.3-11, 2008

COUSINS, D. V.; ELLIS, T. M.; PARKINSON, J.;

McGLASHAN, C. H. Evidence for sheep as a maintenance host for leptospira interrogans serovar hardjo. Veterinary Record, v.124, n.5, p.123-124, 1989.

ELDER, J.K. The influence of environoment factors on the survival of zoonotic bacterial pathogens with special reference to leptospirae. Australian Microbiologist, v.7, p.323-324, 1986.

ELDER, J.K.; McKEON, G.M.; DUNCALFE, F.; WARD, W.H.; LEUTTON, R.D. Epidemiological studies on the ecology of Leptospira interrogans serovar Pomona and Hardjo in Queensland. Preventive Veterinary Medicine, v.3, p.501-521, 1986.

ELLIS, W.A. Leptospirosis as a cause of reproductive failure. The Veterinary Clinics of North America. Food Animal Practice, v.10, p.463-478, 1994.

GALTON, M.M.; MENGES, R.W.; SHOTTS, E.B.; NAHMIAS, A.J.; HEATH Jr., C.W. leptospirosis: epidemiology, clinical manifestations in man and animals and methods in laboratory diagnosis. Atlanta, 1962. 77p. 
FAINE, S.; ADLER, B.; BOLIN, C.; PEROLAT, P. Leptospira and leptospirosis. 2.ed. Melbourne: MediSci, 1999. 272p.

FAVERO, A.C.M.; PINHEIRO, S.R.; VASCONCELLOS, S.A.; MORAIS, Z.M.; FERREIRA, F.; FERREIRA NETO, J.S. Sorovares de leptospiras predominates em exames sorológicos de bubalinos, ovinos, caprinos, equinos, suínos e cães de diversos estados brasileiros. Ciência Rural, v.32, n.4, p.613-619, 2002.

GENOVEZ, M.E.; DEL FAVA, C.; CASTRO, V.; GOTTI, T.B.; DIB, C.C.; POZZI, R.C.; ARCARO, J.R.P.; MIYASHIRO, C.; NASSAR, A.F.C.; CIRRILO, S.L. Leptospirosis outbreak in dairy catlle due to Leptospira spp. serovar Canicola: reproductive rates and serological profile after treatment wiht stretomycin sulfate. Arquivos do Instituto Biológico, São Paulo, v.73, n.4, p.389-393, 2006.

GERRITSEN, M.J.; KOOPMANS, M.J.; OLYHOEK, T. Sheep as maintenance host for Leptospira interrogans serovar Hardjo subtype hardjobovis. American Journal of Veterinary Research, v.55, n.9, p.1232-1238, 1994.

GORDON SMITH, C.E.; TURNER, L.H. The effect of $\mathrm{pH}$ on the survival of leptospires in water. Bulletin World Health Organization, v.24, p.35-43, 1961.

GREGORY, L.; RIZZO, H.; CASTRO, V.; GENTILI, J.; MEIRA JUNIOR, E.B.S.; GENOVEZ, M.E. Leptospirose em ovinos nas regiões de Piedade, Ibiúna e Itu no Estado de São Paulo, BRASIL. In: CONGRESO LATINOAMERICANO DE ESPECIALISTAS EN PEQUEÑOS RUMIANTES Y CAMÉLIDOS SUDAMERICANOS, 5. , 2007, Mendoza. Anales. Mendoza, 2007. p.81-82.

HENRY, R.A.; JOHNSON, R.C. Distribution of the genus leptospira in soil and water. Applied and Environmental Microbiology, v.35, n.3, p.492-499, 1978.

HENRY, R.A.; JOHNSON, R.C.; BOHLOOL, B.B.; SCHMIDT, E.L. Detection of Leptospira in Soil and Water by Immunofluorescence Staining. Applied and Environmental Microbiology, v.21, n.5, p. 953-956, 1971.

HERHOLZ, C.; JEMMI,T.; STARK,K.; GRIOT,C. Patterns of animal diseases and their control. Rivista Trimestrale di Sanità Pubblica Veterinaria, v.42, n.4, p.295-303, 2006.

HERMANN, G.P.; LAGE, A.P.; MOREIRA, E.C.; HADDAD, J.P.A.; RESENDE, J.R.; RODRIGUES, R.O.; LEITE, R.C. Soroprevalência de aglutininas anti-leptospira spp. em ovinos nas mesorregiões sudeste e sudoeste do estado do Rio Grande do Sul, Brasil. Ciência Rural, v.34, n.2, p.443-448, 2004.

KARASEVA, E.V. Ecological features of mammal-carriers of leptospires (L. grippotyphosa) and their role in natural foci leptospirosis. Fauna and Ecology of the Rodents, v.10, p.30-144, 1971.

LEPSCH, I. F. Formação e conservação dos solos. São Paulo: Ed. Oficina de Textos, 2002. 178p.

LEVETT, P.N. Leptospirosis. Clinical Microbiology Reviews, v.14, v.2, p.296-326, 2001.

MÉRIEN, F.; AMOURIAUX, P.; PEROLAT, P.; BARANTON, G.; SANINT-GIRONS, T. Polymerase chain reaction for detection of Leptospira spp in clinical samples. Journal of Clinical Microbiology, v.30, p.22192224, 1992.

MOREIRA, F.M.S.; SIQUEIRA, J.O. Microbiologia e Bioquímica do Solo. Lavras: UFLA, 2002. 626p.

OLIVEIRA, J.B. Pedologia Aplicada. 2.ed. São Paulo: FEALQ, 2005. 574p.

RADOSTITS, O.M.; GAY, C.C.; BLOOD, D.C.; HINCHCLIFF, K.W. Diseases caused by Leptospira spp. In: (Ed.). Veterinary medicine 9.ed. Philadelphia: W.B. Saunders Company, 2005. p.971-986.

RICHTZENHAIN, L.J.; CORTEZ, A.; HEINEMANN, M.B.; SOARESM R. M.; SAKAMOTO, S.M.; VASCONCELLOS, S.A.; HIGA, Z.M.M.; SCARCELLI, E.; GENOVEZ, M.E. A multiplex PCR for the detection of Brucella spp. and Leptospira spp. DNA from aborted bovine fetuses. Veterinary Microbiology, v.87, p.139-147, 2002.

SÃO PAULO. Secretaria de Economia e Planejamento. Região Administrativa de Sorocaba. São Paulo, 2003.

SILVA, E.F.; BROD, C.S.; CERQUEIRA, G.M.; BOURSCHEIDT, D.; SEYFFERT, N.; QUEIROZ, A.; SANTOS, C.S.; KO, A.I.; DELLAGSTIN, O.A. Isolation of Leptospira noguchii from sheep. Veterinary Microbiology, v. 121, n.1-2, p.144-149, 2007.

SMITH, D.J.W.; SELF, H.R.M. Observation on the survival of Leptospira australis A in soil and water. Journal of Hygiene, v.53, p.436-444, 1955.

TORTEN, M., BIRNBAUM, S., KLINGBERG, M. A., SHENBERG, E. Epidemiologic investigation of an outbreak of leptospirosis in the upper Galilee, Israel. American Journal of Epidemiology, v.91, p.52581970.

VAN RAIJ, B.; QUAGGIO, J.A.; CANTARELLA, H.; FERREIRA, M.E.; LOPES, A.S.; BATAGLIA, O.G. Análise Química do Solo para fins de Fertilidade. São Paulo: Fundação Cargill, 1987. 170p.

VIEGAS, E.A.; VIEGAS, S.A.R.A.; CALDAS, E.M.

Aglutininas anti-leptospira em hemo-soro de caprinos e 
ovinos no estado da Bahia. Arquivos da Escola de Medicina Veterinária da Universidade Federal da Bahia, v.5, n.1, p.20-34, 1980.

VIEIRA, S.R. Permeâmetro: novo aliado na avaliação de manejo de solo. O Agronômico, v.47/50, n.único, p.1-32, 1995/1998.
WIKIPÉDIA: a enciclopédia livre. Sorocaba. Disponível em: <http://pt.wikipedia.org/wiki/Sorocaba>. Acesso em: 23 mai. 2008.

Recebido em 28/12/09

Aceito em 3/8/10 